\title{
PROSEA and Flora Malesiana
}

\author{
N. Wulijarni-Soetjipto and B.P. del Rosario
}

\begin{abstract}
N. Wulijarni-Soetjipto ${ }^{1}$ and B.P. del Rosario ${ }^{1,2}{ }^{1}$ PROSEA Foundation Network Office, c/o Herbarium Bogoriense, Jl. Ir. H. Juanda 22, P.O. Box 332, Bogor 16122, Indonesia; ${ }^{2}$-permanent address: Philippine Council for Agriculture, Forestry and Natural Resources Research and Development (PCARRD), Paseo de Valmayor, P.O. Box 425, Los Baños, Laguna 4030, The Philippines) 2003. PROSEA and Flora Malesiana. Telopea 10(1): 11-27. About 15 years after its establishment, the PROSEA Programme has published 16 volumes (18 books) of the PROSEA Handbook series of the 20 planned. All together the 18 books cover c. 5615 species in 6515 printed pages. As many as 580 scientists ( 335 from South-East Asia) have been involved in the preparation of the Handbooks as authors and editors, and more than one quarter contributed to more than one volume. The volumes were published in hardbound and paperback editions. Of the 30000 copies of all paperback edition printed in 1992-2001, a total of 20000 copies have been distributed. By April 2003, another 9 books are expected to appear, estimated to include c. 1600 species in more than 2500 pages. From the PROSEA Handbook series, various derived materials intended for education, training and extension were published by and in the PROSEA participating countries in South-East Asia, and training workshops have been carried out. Beyond the year 2000, PROSEA's mission is to become a leading information provider and disseminator on the efficient and sustainable use of the plant resources of South-East Asia. To execute this mission, PROSEA has been seeking linkages with local, regional and international organisations. In the period 2001-2005, a shift to appropriate information and computer technologis will be the preferred dissemination mode to PROSEA's direct and indirect beneficiaries. PROSEA is looking at possibilities to make the information widely available on the internet to reach a broader public. Several ongoing and planned activities, including contacts with other organisations, to reach PROSEA's goal are highlighted. From the start of its programme until today PROSEA has been using the Flora Malesiana series, and PROSEA receives assistance from a number of plant specialists in the Flora Malesiana region. Cooperation between PROSEA and Flora Malesiana will continue to be of mutual benefit. PROSEA's experience in utilising the Flora Malesiana series, and some topics of possible joint activities between the two programmes are presented.
\end{abstract}

\section{Introduction}

PROSEA (Plant Resources of South-East Asia) is:

- an international programme focusing on plant resources of South-East Asia.

- interdisciplinary, covering the fields of agriculture, forestry, horticulture and botany.

- a research programme, making knowledge available for education and extension.

- ecologically focused on promoting plant resources for sustainable tropical land-use systems.

- committed to conservation of biodiversity.

- committed to rural development through diversification of resources and application of farmers' knowledge.

\section{Organisation}

PROSEA started in 1986 as a Project initiated by the Wageningen Agricultural University (WAU) in the Netherlands. In 1988 a set of agreements of Cooperation were concluded between WAU and five institutions in five countries in South-East Asia 
(Malaysia, Indonesia, Papua New Guinea, the Philippines and Thailand), and in 1990 the Project became a non-profit Foundation under Indonesian law, with an international charter, domiciled in Bogor. In 1991 one institution from Vietnam joined the Foundation.

PROSEA is governed by a Board of Trustees. Members of the Board consist of representatives of the participating institutions, donor agencies and of personal title. The Chairman and Vice-Chairman form the Executive Board, with responsibility for policy-decisions in between meetings of the Board of Trustees. The Board of Trustees meets once a year.

The programme infrastructure, operational since 1988, consists of a Network Office located in Bogor (Indonesia), and a Publication Office in Wageningen (the Netherlands). The Network Office coordinates a network of 6 Country Offices in 6 South-East Asian Countries. The Publication Office coordinates a large informal network of editors and authors of the PROSEA core publications.

\section{Objectives}

The PROSEA Programme has four objectives:

- to compile, review and summarise the existing wealth of information on the plant resources of South-East Asia for education, extension, research, and industry.

- to build and maintain a computerised Databank on the plant resources of South-East Asia.

- to publish information on the plant resources of the region in an illustrated, multi-volume handbook.

- to support additional activities that enhance dissemination of this information published in the PROSEA Handbook series or compiled in the Databank.

\section{Participating institutions}

The institutions participating in the PROSEA Programme are:

- Forest Research Institute of Malaysia (FRIM), Kepong, Malaysia; hosting the Country Office Malaysia.

- Indonesian Institute of Sciences (LIPI), Jakarta, Indonesia; hosting the Network Office SouthEast Asia and the Country Office Indonesia.

- Institute of Ecology and Biological Resources (IEBR), Hanoi, Vietnam; hosting the Country Office Vietnam

- Papua New Guinea University of Technology (UNITECH), Lae, Papua New Guinea; hosting the Country Office Papua New Guinea.

- Philippine Council for Agriculture, Forestry and Natural Resources Research and Development (PCARRD), Los Baños, Laguna, Philippines; hosting the Country Office Philippines.

- Thailand Institute of Scientific and Technological Research (TISTR), Bangkok, Thailand; hosting the Country Office Thailand.

- Wageningen University (WU), Wageningen, the Netherlands; hosting the Publication Office.

\section{Target groups}

The target groups of the programme are: direct users, i.e. those professionally concerned with plant resources in South-East Asia and working in the fields of 
education, extension, research, and commercial production. These include, among others, lecturers and students of colleges and universities, scientific staff of Research and Development establishments, subject specialists, and libraries; and indirect users, i.e. those in South-East Asia depending directly on plant resources and obtaining relevant information through extension. They are individual farmers applying the information in their actual production activities.

\section{Implementation}

Until the year 2000 the programme was implemented in 4 phases. The main activities carried out during each phase are as follows:

Preliminary phase (1985-1986): During this period a feasibility study was made by Wageningen Agricultural University, Proposal for a handbook was published in 1986, and promotion of the undertaking was carried out.

Preparatory phase (1987-1990): Network Office South-East Asia was established in Bogor (Indonesia), basic documents for discussion were prepared, PROSEA Databank was established. In this period the First PROSEA International Symposium was held in 1989 in Jakarta (Indonesia) with the objective to discuss the scientific and organisation aspects of the whole PROSEA undertaking based on the experience gained from 1987 to early 1989.

First implementation phase (1991-1995): PROSEA Databank was developed, ten earlier volumes of the PROSEA Handbook were produced. Later in the period, first efforts in producing materials derived from the Handbook were made. The Second PROSEA International Workshop was held in 1994 in Cisarua (Indonesia) with the objectives (1) to highlight the importance of the plant resources of South-East Asia, (2) to review the progress made by the PROSEA Foundation during the First Implementation Phase in achieving international cooperation, in developing a documentation and information system and in publication of the Handbook, (3) to make recommendations for the Second Implementation Phase (1996-2000) on all aspects of the programme, with special attention to dissemination of information.

Second implementation phase (1996-2000): Handbook production and Databank development continued, derived materials were actively produced, and first steps were made in PROSEA Electronics ${ }^{\circledR}$ by producing CD-ROMs. The third PROSEA International Workshop was held in 1999 in Bogor (Indonesia) with the objectives (1) to highlight the importance of the plant resources of South-East Asia and the unique position of PROSEA in this respect, (2) to review the progress made by the PROSEA Foundation during the Second Implementation Phase in achieving its targets, particularly in its electronic and printed-publication programme, and (3) to formulate a new PROSEA mission for a new era while the Publication Office undertakes a Finalisation Phase 2001-2002 for completion of the Handbook.

The historical background, activities and progress of the PROSEA programme from 1987 until today has been reported by our colleague Dr. P.C.M. Jansen (First General Editor of the PROSEA Handbook) in the Flora Malesiana Bulletin; these have appeared from Vol. 9 No. 4 onwards. The PROSEA outputs, the activities beyond 2000 and their link with Flora Malesiana will be highlighted in this paper. 


\section{PROSEA core outputs}

For the years beyond 2000, PROSEA has accumulated information and knowledge on plant resources of South-East Asia in different core outputs and various derived materials. They will be utilised as capital for activities in the period 2001-2005.

The PROSEA Core outputs consist of PROSEA Databank, multi-volume Handbook, the Basic list of species and commodity groupings, Bibliographies, CD-ROMs, and Home page.

\section{The PROSEA databank}

The PROSEA Databank at present consists of 7 databases (BASELIST, CATALOG, PREPHASE, ORGANYM, PERSONYM, TEXTFILE, and PHOTFILE). The Databank is physically available and accessible at the PROSEA Offices in South-East Asia and the Netherlands.

- BASELIST: is a database of botanical names and uses of c. 6200 plant resources of South-East Asia. It is based on the books of Heyne (1927), Burkill (1935), Brown (1941-1943), and Reyes (1938). It forms the skeleton of the PROSEA Handbook.

- CATALOG: is a database of international literature references derived from 5 parent databases, i.e. AGRICOLA, AGRIS, BIOSIS Previews, CAB Abstracts and TROPAG. As of July 2001 the database contains 191830 records.

- PREPHASE: is a database of less-accessible literature references from South-East Asia. It contains information of more localised importance (articles from national journals, reports and books in local languages, student theses, etc.), which are scanned manually by the Country Offices. As of July 2001 it contains 60340 records, of which more than 30\% have abstracts in English.

- ORGANYM: is a database of institutions active in the field of plant resources of South-East Asia. There are 735 records containing basic identification parameters and information on activities and main publications of the respective institutions. This database has been discontinued at regional level.

- PERSONYM: is an expert database, providing information on the research activities and major publications of individual scientists. It contains 5900 records. This database has also been discontinued at regional level.

- TEXTFILE: is a database containing the text of the PROSEA Handbook volumes, each genus or species article being a record. As of July 2001 the database contains 5430 records.

- PHOTFILE: is a database containing images of photographs and line-drawings of plant resources. It is particularly intended to make PROSEA CD-ROMs more attractive, but they can also be used for the production of derived materials under proper references. As of July 2001 it contains 6765 records.

\section{The Handbook}

From 1989 until 2000, 18 books of 16 Handbook volumes (of the 20 volumes planned) have been published covering more than 5600 species in 6515 pages (Table 1).

The Handbook volumes are the result of an orchestrated effort of about 580 scientists from 39 countries contributing to the volumes as authors of manuscripts and/or members of the editorial team. Of them 335 are from South-East Asia (Indonesia 134, Malaysia 72, Papua New Guinea 11, Philippines 48, Singapore 2, Thailand 42, Vietnam 26), 106 from the Netherlands, and 245 from other countries. Of the 580 scientists, 167 
contributed to more than one volume (Table 2), thus the frequency of their involvement in the Handbook production is more than 935. Taxonomists have played an important role in the preparation of the Handbook.

Table 1. PROSEA Handbook volumes published from 1989 to 2000.

$\begin{array}{llccc}\text { No. } & \text { Title } & \text { Year published } & \text { No. of species } & \text { No. of pages } \\ 1 & \text { Pulses } & 1989 & 25 & 107 \\ 2 & \text { Edible fruits and nuts } & 1991 & 390 & 447 \\ 3 & \text { Dye and tannin-producing plants } & 1991 & 111 & 196 \\ 4 & \text { Forages } & 1992 & 359 & 300 \\ 5(1) & \text { Timber trees: Major commercial timbers } & 1993 & 596 & 610 \\ 5(2) & \text { Timber trees: Minor commercial timbers } & 1995 & 850 & 655 \\ 5(3) & \text { Timber trees: Lesser-known timbers } & 1998 & 1778 & 859 \\ 6 & \text { Rattans } & 1993 & 134 & 137 \\ 7 & \text { Bamboos } & 1995 & 77 & 189 \\ 8 & \text { Vegetables } & 1994 & \text { C. } 225 & 412 \\ 9 & \text { Plants yielding non-seed carbohydrates } & 1996 & 103 & 237 \\ 10 & \text { Cereals } & 1996 & 40 & 199 \\ 11 & \text { Auxiliary plants } & 1997 & 213 & 389 \\ 12(1) & \text { Medicinal and poisonous plants } & 1999 & 389 & 711 \\ 13 & \text { Spices } & 1999 & 126 & 400 \\ 16 & \text { Stimulants } & 2000 & 55 & 201 \\ 18 & \text { Plants producing exudates } & 2000 & 79 & 189 \\ 19 & \text { Essential-oil plants } & 1999 & 68 & 277 \\ \text { Total } & \text { (16 volumes, 18 books) } & & \mathbf{6 5 1 5}\end{array}$

Table 2. Frequency of scientists' contributions to PROSEA Handbook series, 1989-2000.

$\begin{array}{lcc}\text { Contribution } & \text { No. of scientists } & \text { Frequency } \\ 1 \text { book } & 413 & 413 \\ 2 \text { books } & 88 & 176 \\ 3 \text { books } & 38 & 114 \\ 4 \text { books } & 21 & 84 \\ 5 \text { books } & 7 & 35 \\ 6 \text { books } & 7 & 42 \\ 7 \text { books } & 1 & 7 \\ 9 \text { books } & 2 & 18 \\ 12 \text { books } & 1 & 12 \\ 18 \text { books } & 2 & 36 \\ \text { Total } & \mathbf{5 8 0} & \mathbf{9 3 7}\end{array}$


Of the 580 contributors, 106 scientists from 17 countries were involved in the editing work: 4 scientists (from 2 countries) as general editors of the series, 33 (from 8 countries) as volume editors, and 69 (from 17 countries) as associate editors. In the production of the Handbook effort has been made to keep the number of South-East Asian scientists involved either as authors or as volume editors always in balance with that from outside the region.

The Handbook volumes have been published as hardbound editions for distribution in developed countries and as a paperback low-price edition for distribution in developing countries. A total of 45895 copies have been printed (hardbound 15 514; paperback 30 380) of which 30767 have been distributed throughout the world (10 791 for the hardbound, as of end 2000; 19976 for the paperback, as of July 2001).

The text of the Handbook volumes forms the database TEXTFILE.

\section{Basic list of species and commodity groupings}

From the database BASELIST have been published PROSEA: Basic list of species and commodity grouping: Version 1 (paperback, 1989) and PROSEA: Basic list of species and commodity grouping: Final version (hardbound, 1991). The production of Version 1 involved more than 40 plant taxonomists and other plant specialists from 6 countries (the Netherlands, United Kingdom, Denmark, Germany, United States and Australia). This version was distributed in 1989 within the PROSEA Network only. The production of the Final version involved 70 plant taxonomists and other plant specialists from 11 countries (the Netherlands, Austria, Denmark, France, Germany, Norway, United Kingdom, United States, Australia, Indonesia and Malaysia).

This Basic list contains c. 6200 species and is intended to help editors and authors of the PROSEA Handbook to check correct scientific names, and to decide which species should be considered for inclusion in the Handbook and which commodity group each species can best be assigned to. This list is used as a starting point for each Handbook volume. Besides, it is also used in scanning literature for the CATALOG and PREPHASE databases. It was reprinted in 1993 (paperback) and distributed to those interested in the correct scientific names of useful plants occurring in South-East Asia.

\section{Bibliographies}

The database PREPHASE has been extracted to produce PROSEA Bibliographies, each volume of which appeared soon after the publication of the Handbook volume of the same commodity group. Earlier volumes of the Bibliographies were published in printed form, later volumes in CD-ROM. Table 3 shows the Bibliographies that have been published so far. 
Table 3. PROSEA Bibliographies.

$\begin{array}{ll}\text { No. } & \text { Commodity group } \\ 1 & \text { Pulses } \\ 2 & \text { Edible fruits and nuts } \\ 3 & \text { Dye and tannin-producing plants } \\ 4 & \text { Forages } \\ 5(1) & \text { Timber trees: Major commercial timbers } \\ 5(2) & \text { Timber trees: Minor commercial timbers } \\ 5(3) & \text { Timber trees: Lesser-known timbers } \\ 6 & \text { Rattans } \\ 7 & \text { Bamboos } \\ 8 & \text { Vegetables } \\ 9 & \text { Plants yielding non-seed carbohydrates } \\ 10 & \text { Cereals } \\ 11 & \text { Auxiliary plants } \\ 13 & \text { Spices } \\ 19 & \text { Essential-oil plants }\end{array}$

Year published
1990
1993
1991
1994
1994
$1996)$
1998
1995
1996
1995
1999
1999
1997
2000
2000

No. of records (approximate)

600

2 parts 4400

360

950

2 parts 260

1025

1800

515

505

2 parts 3100

in CD-ROM 4700

in CD-ROM 3625

2380

in CD-ROM together with Bibliography 193395

in CD-ROM together with Bibliography 131020

Total 30975

\section{CD-ROMs}

From the database TEXTFILE, CATALOG, PREPHASE and PHOTFILE the following CD-ROMs have been produced:

- Test Version (1994), containing PROSEA Handbook volumes 1-4, CATALOG 1-4, Bibliography 1-4. PROSEA/Pudoc-DLO, Wageningen, the Netherlands.

- Version 1 (1997), containing PROSEA Handbook volumes 1-8, Bibliography 1-8. PROSEA/Pudoc-DLO, Wageningen, the Netherlands.

- Vegetables (1997), containing PROSEA Handbook 8, Bibliography 8, Photographs. ETI/PROSEA/Pudoc-DLO, Amsterdam, the Netherlands.

- Forestry Compendium (1998); a result of collaboration between CABI, CIFOR and PROSEA, issued by CABI, Wallingford, UK.

- Timber trees (1999/2000), containing PROSEA Handbook volumes 5(1), 5(2), 5(3), Bibliography 5(1), 5(2), 5(3), Photographs, Identification keys for wood properties and anatomy. ETI/PROSEA/Pudoc-DLO, Amsterdam, the Netherlands.

- Fruits and nuts (1999), containing Handbook volume 2, Bibliography 2, Photographs. ETI/PROSEA/Pudoc-DLO, Amsterdam, the Netherlands.

- Forestry Compendium (2000); a result of collaboration between CABI, CIFOR and PROSEA (Global Module), issued by CABI, Wallingford, UK. 


\section{Homepage}

Information regarding PROSEA in general, PROSEA Databases, PROSEA Newsletter, PROSEA Handbook and spin-off products has been made available on the internet since 1998 (the Netherlands) and since September 2000 (Indonesia) at the following websites: for the Netherlands: http:/ / www.prosea.nl and http:/ / www.prosea.net and for Indonesia: http://www.proseanet.org.

\section{PROSEA derived products}

Various products have been produced by the PROSEA Offices derived from the PROSEA Handbook and Databank, i.e. translations, booklet series, non-series booklets, leaflet series, directories, special bibliographies, video presentations, radio broadcasts, game cards, calendars, and other outputs. The PROSEA Handbook and Databank have also been used in workshops/training programmes on certain topics.

\section{Translations}

Many local researchers, lecturers and students in South-East Asia, especially in Indonesia, Thailand and Vietnam still have difficulty in understanding texts in English. To reach the wider audience of the PROSEA Handbook series, certain volumes have been translated into local languages and published by the Country Offices. So far 5 volumes have been translated and published in Indonesian, 7 volumes in Thai, 2 volumes in Vietnamese, and 1 volume in Filipino.

\section{Booklet series}

For the intermediate beneficiaries (local subject specialists) of the PROSEA Handbook, the Country Office Indonesia publishes Seri Pengembangan PROSEA [PROSEA Development Series] in Indonesian. So far the following issues have been published: No. 1-12(1).2 (1993-2000).

\section{Non-series Booklets}

Various booklets were published from 1995 to 1998 mostly in local languages:

- Manual for the cultivation of lowland vegetables (1995, in Indonesian). Issued by the Country Office Indonesia.

- Trees for life (1995, in Indonesian). Issued by the Country Office Indonesia.

- A guide to root diseases (1997, in Malay). Issued by the Country Office Malaysia.

- Forest species for landscaping and urban planting (1997). Issued by the Country Office Malaysia.

- Medicinal vegetables in South-East Asia (1998, in Thai). Issued by the Country Office Thailand.

- Manual for identification of wood in the field (1997, in Indonesian). Issued by the Network Office Bogor.

- Manual for the identification of forest trees in Indonesia (1998, in Indonesian). Issued by the Network Office Bogor.

- Techniques for producing planting materials of forest trees (1998, in Indonesian). Issued by the Country Office Indonesia.

- Introduction to the efficient and sustainable use of forest trees (1998, in Indonesian). Issued by the Country Office Indonesia. 


\section{Leaflet series}

For field extension officers the Country Office Indonesia publishes Lembaran Informasi PROSEA [PROSEA Information Leaflet]. The following have been issued: Vol. 1, No. 1-18 (1993-1997); Vol. 2, No. 1-14 (1997-2000).

Another PROSEA Information Leaflet has been published in Vietnamese by the Country Office Vietnam. The following issues have appeared: Vol. 1, No 1-5 (1996), Vol. 2, No. 1-6 (1997), Vol. 3, No. 1-5 (1998), Vol. 4, No. 1-6 (1999), No. 1-6 (2000).

The Country Office Philippines published leaflets on edible fruits and nuts in 1992-1997 (81 issues) in English and on vegetables in 1999 (19 issues) in Filipino, intended for farmers.

The Country Office Thailand published leaflets on timber resources in 1997-1998 (14 issues) in Thai.

\section{Directories}

Three directories have been issued by the Country Office Philippines based on PERSONYM:

- PROSEA Philippines' Directory of specialists in agronomy and horticulture 1994. Issued in 1995.

- PROSEA Philippines' Directory of specialists in forestry/agroforestry 1997. Issued in 1997.

- PROSEA Philippines' Directory of specialists on medicinal and poisonous plants 1998. Issued in 1998.

\section{Special bibliography}

Abstract bibliography Crop Science Research in the Philippines 1970-1994 was issued by the Country Office Philippines in 1996. It is an extract of the PREPHASE database.

\section{Video presentation}

'Know your common trees' (1996), issued by the Country Office Malaysia.

\section{Radio broadcasting}

To enhance dissemination of the PROSEA information base to farmers in rural areas, various topics have been broadcast by the Country Office Indonesia in the weekly 'Siaran Pedesaan' [Rural Broadcast] of the RRI (Indonesia Radio Broadcasting) of Bogor.

\section{Game cards}

Game cards to introduce plant resources to school children have been issued:

- X-cellent plants fun cards (1998). Issued by the Country Office Philippines.

- Playing cards Fruits and vegetables (1999). Issued by the Country Office Indonesia.

- X-cellent trees fun cards 1 (1999). Issued by the Country Office Philippines.

- X-cellent trees fun cards 2 (2000). Issued by the Country Office Philippines.

\section{PROSEA calendars}

Three promotional bureau calendars have been issued by the Country Office Philippines in 1998-2000 for the year 1999, 2000 and 2001. 


\section{Other outputs}

- Pedoman identifikasi pohon-pohon Dipterocarpaceae. Kalimantan (1999); Indonesian version of the English edition. Issued by the Country Office Indonesia.

- Pedoman identifikasi pohon-pohon Dipterocarpaceae. Sumatera (1999); Indonesian version of the English edition. Issued by the Country Office Indonesia.

- Pedoman identifikasi pohon-pohon Dipterocarpaceae. Jawa sampai Niugini (1999); Indonesian version of the English edition. Issued by the Country Office Indonesia.

- PROSEA Book Reviews 1989-1999. Issued by the Publication Office, Wageningen.

- Training Module (1999) for Summer Environment Youth Camp (Eco-Camp). Issued by the Country Office Philippines.

\section{PROSEA beyond 2000}

The PROSEA Programme has been focused and directed from the documentation stage (Handbook production and Databank development) and dissemination stage (production of translations of the Handbook and derived materials) to the utilisation stage of the PROSEA information base for biodiversity conservation, education, industry, agroforestry, planning, extension, etc.

The mission of PROSEA beyond 2000 was, therefore, formulated and recommended during the Third PROSEA International Workshop in November 1999 and states: 'In view of the importance of plant information for mankind and biodiversity conservation, and the unique position of PROSEA in this respect, PROSEA strives to be a leading information provider and disseminator on the plant resources of South-East Asia for their efficient and sustainable use. Emphasis will be on lesser-known plants, and information services will be demand-driven'.

To carry out the mission, the PROSEA programme activities for the period 2001-2005 will cover:

- Finalisation of Handbook production

- Databank maintenance and development

- Development of PROSEA Electronics ${ }^{\circledR}$ (Webdatabases)

- Active production of derived materials

- Establishment of Country Office websites

- Establishment of Community Websites

- Reduction of the role of Wageningen University (end 2002)

- Extension of PROSEA membership (Laos, Cambodia, Myanmar)

\section{Finalisation of Handbook production}

The years 2001-2002 will be a transitional period for the Publication Office that should finalise the production of the Handbook series. Three books are expected to be published before the end of 2001, namely:

No 12(2) : Medicinal and poisonous plants 2, treating c. 410 species in c. 780 pages

No 14 : Vegetable oils and fats, treating c. 55 species in c. 230 pages

No 15(1) : Cryptogams: Algae, treating c. 220 species in c. 320 pages

Another three books, that will be the last to be managed by the Publication Office in Wageningen, are planned to be sent to the printer in Wageningen before the end of 2002, and expected to be ready for distribution in April 2003. Those books are:

No. 12(3): Medicinal and poisonous plants 3, treating c. 530 species in c. 660 pages

No. 15(2): Cryptogams: Ferns and fern allies, treating c. 100 species in c. 270 pages

No 17: Fibre plants, treating c. 250 species in c. 500 pages 
Thus, by April 2003, a total of 19 Handbook volumes (comprising 24 books) should be available, covering over 7000 species in more than 9000 pages, involving more than 650 scientists in their production.

After the year 2002, publication activities of the Handbook will be transferred to the Network Office in Bogor. The following volumes are expected after 2003:

No 15(3): Cryptogams: Fungi

No 20: Ornamental plants

\section{Active production of derived materials}

At the Country Office level, production of translations of the Handbook volumes and derived material continues.

\section{Databank maintenance and development}

During the period 2001-2005, the existing PROSEA databases TEXTFILE, PREPHASE, PHOTFILE, and CATALOGUE will be maintained and further developed. The text of the newly published Handbook volumes will be incorporated gradually in TEXTFILE. Scanning literature references for PREPHASE continues to pay more attention to lesser-known species. The quality of PREPHASE will be improved through editing work. All line-drawings published in the newly published Handbook volumes will be incorporated in PHOTFILE. Meanwhile, photographs and drawings of species for which no drawing is available yet in PHOTFILE will be sought through contacts with other organisations and individual scientists. It is expected that by December 2002 the TEXTFILE, PREPHASE, PHOTFILE and CATALOG databases will contain about 5950; 67 500; 8 800; and 254150 records, respectively.

\section{Development of PROSEA electronic products}

Three PROSEA databases will be integrated in the PROSEA homepage (http://www.proseanet.org), i.e. TEXTFILE, PREPHASE and PHOTFILE. A trial version of TEXTFILE online was started early in 2001. From 2002 onwards, records in the TEXTFILE database will gradually be accessible online. Complete records of PREPHASE with abstracts will also gradually be put on the internet. PHOTFILE online will cover a selection of images from the off-line PHOTFILE database. For the first few years access to the databases online will be free of charge for personal use. It is expected that by December 2002 the TEXTFILE online, PREPHASE online and PHOTFILE online will contain about 1200, 2100 and 1200 records, respectively.

\section{Establishment of Country Office websites}

To enhance the distribution and dissemination of the PROSEA information base to the direct and indirect target beneficiaries, Country Office websites are to be established. As of August 2001 two Country Offices have established their respective websites: Philippines and Indonesia.

The website of the Country Office Philippines has been developed as an integral component of the PCARRD-MIKS (Management Information and Knowledge System): http://www.pcarrd.dost.gov.ph/prosea/default.htm. The site has a hyperlink to the PROSEA home page. The website covers the following sections: PROSEA Databases, general information on Country Office Philippines, Publications and services (PROSEA core publications), Country Office publications, and Herbal homepage. 
The website of the Country Office Indonesia has been developed as an integral component of the PROSEA homepage: http://www.proseanet.org/Indonesia/. The website covers the sections on general information, publications of the Country Office Indonesia, 'Katalog tumbuhan berguna' [Catalogue of useful plants], Mitra PROSEA [Friends of PROSEA], and collaboration with other organisations. The text is in Indonesian. The website has links to DAFEP (Decentralised Agricultural and Forestry Extension Project) and BIPP (Balai Informasi Penyuluhan Pertanian) [Agricultural Information Extension Center].

\section{Establishment of the Community Websites}

Community websites are useful in the chain of information transfer from an international information (knowledge) base to local application. In collaboration with other organisations the Country Office Philippines and Country Office Indonesia have recently established community websites in their own countries.

As a strategy to reduce poverty and improve health situations especially in rural areas, the Country Office Philippines, in collaboration with RED (Rural Enterprise Development) Foundation, has established the PROSEA Herbal Homepage, using PROSEA volume 12(1): Medicinal and poisonous plants 1 as a source. The homepage is an internet based information service on known medicinal plants which aims to disseminate technologies and information on herbal medicine for alternative health care. The home page forms a section of the website of the Country Office Philippines. The PROSEA Herbal homepage contains 5 main sections: Species list, Technocatalogue, Indication index, Kitchen technologies, and Frequently asked Questions.

As a strategy to integrate the PROSEA information base into the research-extension mechanism in Indonesia, the Country Office Indonesia in collaboration with DAFEP (Decentralised Agricultural and Forestry Extension Project) of the World Bank in Indonesia established Community Websites in three locations in Central Java, i.e. Bantul, Kulon Progo and Magelang districts. The website of Bantul is http:/ / www.dafep.org/bantul, that of Kulon Progo is http:/ / www.dafep.org/kulonprogo and that of Magelang is http://www.dafep.org/magelang. Each Community Website contains information on organisation, potential of the area, development potential, commodity of top priority, market prices, research-extension network in Indonesia and a hyperlink to the website of the Country Office Indonesia.

\section{Reduction of the role of Wageningen University}

When the last six volumes of the Handbook are published, the role of the Publication Office (hosted at Wageningen University) will be terminated and publication activities will be transferred to the PROSEA Network Office in Bogor. The Publication Office will be replaced by a sort of Country Office Netherlands. Meanwhile, Wageningen University will coordinate the PROTA (Plant Resources of Tropical Africa) programme, a sister programme of PROSEA, and will remain a member of the PROSEA Board of Trustees.

\section{Extension of PROSEA membership}

South-East Asia also covers Cambodia, Laos and Myanmar. Information on plant resources of these three countries in the PROSEA Databank is very limited. Participation of these three countries in the PROSEA undertaking will surely enrich the PROSEA information base making it beneficial to those outside the three countries. The Third PROSEA International Workshop in 1999 was attended by representatives 
from Laos and Myanmar who expressed their wish that their respective countries might join the PROSEA Network.

\section{Cooperation with other organisations}

In implementing its programme, PROSEA has received cooperation from many national as well as international organisations and individual scientists. Among others, these include:

- PROSEA participating institutions: LIPI (Indonesia), FRIM (Malaysia), PCARRD (the Philippines), TISTR (Thailand), IEBR (Vietnam), UNITECH (Papua New Guinea) and WU (the Netherlands). They coordinate PROSEA activities, provide manpower, working space and facilities for PROSEA Offices, and matching funds.

- Pudoc-DLO, Wageningen, the Netherlands. This Centre of Agricultural Publishing and Documentation provides online service for the development of the CATALOG database, and published and distributed earlier volumes of the PROSEA Handbook and integral CD-ROMs.

- Herbaria in South-East Asia and other countries, by providing authors and editors for PROSEA Handbook volumes, and access to herbarium collection for consultation.

- Research institutes and universities in South-East Asia, by providing authors and editors forPROSEA Handbook volumes, and manpower to scan information sources for the PROSEA Databank.

- ETI (Expert Centre for Taxonomic Identification), University of Amsterdam, the Netherlands, for the production of PROSEA Commodity Groups' CD-ROMs.

- CAB International (Wallingford, Oxon, United Kingdom), for production of the CD-ROM CABI/PROSEA Crop Protection Compendium, and together with CIFOR (Center for International Forestry Research, Bogor, Indonesia), for production of the CD-ROM CABI/CIFOR/PROSEA 'Forestry Compendium'.

- ICRAF (International Centre for Research in Agroforestry) South-East Asia, for among others launching of PROSEA 11 Auxiliary plants, and in the development of webdatabase on quantitative tree properties.

- Backhuys Publishers (Leiden, the Netherlands), for the publication and distribution of the hardbound edition of later PROSEA Handbook volumes, and the distribution of mediumpriced editions of the volumes.

- At the Country Offices' level, with national agencies, NGOs, ministries, industries and others.

\section{The importance of Flora Malesiana for PROSEA}

The Flora Malesiana (FM) series is an invaluable source of botanical information and knowledge on plants in the Malesian region (Malaysia, Indonesia, Singapore, Brunei Darussalam, the Philippines and Papua New Guinea), wild as well as cultivated.

PROSEA has used the FM series in the compilation of PROSEA: Basic list of species and commodity groupings, a checklist used as a starting point in the preparation of the PROSEA Handbook series. Besides this, the FM series has also been consulted during the preparation of the individual volumes of the Handbook. PROSEA adopted all the family treatments and followed the nomenclature used in the FM series. For families not yet treated in the FM series, PROSEA has to refer to other existing publications.

As a compiler of plant information, PROSEA would not be able to operate without the existence of the FM and other floras of the South-East Asian region such as Flora of Java, Tree flora of Malaya, Tree flora of Sabah and Sarawak, Flora of Thailand, and Flora of Laos, 
Cambodia and Vietnam. PROSEA is very grateful to the Foundation FM, and to the publishers and editors of the above-mentioned floras for the important botanical sources of information they provide.

\section{Expectations for Flora Malesiana}

The following are our expectations and comments based on the first author's and colleagues' experiences in using the FM series during the preparation of the PROSEA Handbook volumes.

For every family in the FM series, useful and cultivated plants of South-East Asia need be given proper treatment, not the same as in the PROSEA Handbook series, but with aspects that will be useful for PROSEA and other users (non-taxonomists) of the series, e.g. taxonomic aspects, correct naming, taxonomy of cultivars, relationship with wild plants, etc. Descriptions of species should not be too brief and should be consistently presented to enable comparison of plant parts. For rather important cultivated plants, information on vernacular names and uses needs to be added.

Cultivars and cultivar groups also need to be more properly treated in other floristic publications in South-East Asia.

FM series is important for plant taxonomists working on the flora of Malesia but it is also important for many other specialists from various disciplines. The knowledge of plant classification is also useful to non-plant taxonomists, e.g. as a tool for identification and registration. Since they are not too familiar with many botanical terms and scientific (Latin) plant names, it will be easier for them (without the help of a plant taxonomist) to use the FM series if a glossary of technical terms and an index of vernacular plant names are available in each volume of the series.

The inclusion of both a glossary and an index will be most welcome. The late Prof. Kalkman, in his paper presented at the First PROSEA International Symposium in 1989 , stated that the results of research in plant systematics should not only be beneficial to plant taxonomists but should also be accessible to specialists who are non-plant taxonomists, e.g. horticulturists, foresters, phytochemists, plant breeders, etc. throughout the world, the number of which is much greater than that of the plant taxonomists.

To gain wider usage, the FM series would need to be more attractive and more user friendly. The number of illustrations could be increased to cover more species. The excellent illustrators, herbaria and botanical gardens occurring in South-East Asia could be employed far more.

Cultivated plants need to be better represented in the South-East Asian herbaria to enable people to get a better understanding of cultivars and cultivar groups for their sustainable utilisation and conservation, and to avoid their being described as species.

\section{PROSEA and Flora Malesiana collaboration}

Although there is no official collaboration between the PROSEA Foundation and the Foundation Flora Malesiana, collaboration between PROSEA and individual FM specialists has occurred since the start of the PROSEA programme (Preliminary phase: 1985-1986) e.g. in the verification of scientific names, as contributors of manuscripts on certain taxa, as associate editors or editors of certain volumes of the PROSEA Handbook, or of other PROSEA core products, and as instructors in various training courses. PROSEA is very grateful to them, especially since, besides contributing, they are also acting as users of the PROSEA products. 
PROSEA will maintain and strengthen collaboration with individual FM specialists and will be pleased to continue collaborating with the Foundation FM and partners for mutual benefit. Some examples of what can be considered activities are:

Update of botanical information in the TEXTFILE database: The PROSEA Handbook volumes will not be revised before 2010. However, information on taxa published in the Handbook which are already in the database TEXTFILE need to be updated and new information added. To develop this database, assistance from botanical specialists is needed.

Contribution and uses of plant images: PROSEA is developing the PHOTFILE database. Of the taxa published in the Handbook volumes many still have no photograph or line-drawing. Contribution of plant images from the FM specialists or organisations to the database is most welcome. On the other hand, images in the PHOTFILE database can be used by FM specialists for illustrating publications on request to the PROSEA Foundation.

Production of booklets and other materials for education: PROSEA core products can be used for producing materials for education. FM specialists together with PROSEA could produce e.g. : (1) Publications on important plant resources (e.g. 100 species per country in South-East Asia) for primary and secondary school children which would cover interesting facts, identification, illustrations, information on how to grow and maintain plants, etc., (2) Good simple botany books for teachers, with numerous familiar examples and correct descriptions of species, (3) Publications on indigenous and imported plant products to be found in local markets, with photographs and drawings, (4) Publications per country or region for tourists interested in plants, e.g. on fruits, flowers, interesting trees, etc., with enough illustrations and details to enable identification.

Training courses at regional and national levels: PROSEA can contribute to training courses on e.g. plant taxonomy, economic botany, para-taxonomy and other topics, especially for young people, by providing e.g. a list of South-East Asian genera which are badly in need of critical taxonomic studies, and by making the PROSEA core products accessible to the trainees and instructors. FM specialists could help in the teaching programmes.

Hyperlink of PROSEA web databases with those of Flora Malesiana: There are three PROSEA databases available online, i.e. TEXTFILE, PREPHASE, and PHOTFILE. These databases can be hyperlinked with those of Flora Malesiana and partners. In that way a gap in certain plant information in the PROSEA Webdatabases can be filled by the Webdatabases of Flora Malesiana or its partners, and vice versa.

Production of PROSEA 20 and PROSEA 15(3): When the time comes, interested FM specialists will be invited to be involved in the production of PROSEA volumes 20 'Ornamental plants' and PROSEA 15(3) 'Cryptogams: Fungi' as members of the task force, authors of manuscripts on certain taxa and as members of the editorial team. PROSEA will be grateful if the Foundation FM and partners could find ways to fund these two publications.

Production of CD-ROMs: In cooperation with ETI (Amsterdam) and Pudoc-DLO (Wageningen) the following PROSEA commodity-groups have been published in CDROMs: 'Vegetables' (1997), 'Edible fruits and nuts' (1999) ,'Timber trees' (1999 \& 2000), and 'Rattans and Bamboos' (2001). However, in 2001 the PROSEA policy on electronic publishing was shifted to the establishment of Web databases. Depending on the demand and funds available, PROSEA may collaborate someday with FM or other organisations in the production of other CD-ROMs with materials extracted from the PROSEA Web databases, especially TEXTFILE and PHOTFILE online. 


\section{Donor agencies}

To execute its programme, PROSEA has received financial support from the coordinating institutions (FRIM, Malaysia; LIPI, Indonesia; IEBR, Vietnam; UNITECH, Papua New Guinea; PCARRD, the Philippines; TISTR, Thailand; WU, the Netherlands). It has also received general financial support from the following donor agencies:

- Finnish International Development Agency (FINNIDA): 1991-1995.

- Finnish Department for International Development Cooperation (DIDC): 1996-2000.

- Netherlands Ministry of Agriculture, Nature Management and Fisheries: 1987-1990, 1991-1995, 1996-2000.

- Netherlands Ministry of Education and Science: 1987-1990, 1991-1995, 1996-2000, 2001-2005.

- Netherlands Ministry of Foreign Affairs, Directorate General for International Cooperation (DGIS): 1987-1990, 1991-1995, 1996-2000, 2001-2005.

- Ministry of Forestry, Republic of Indonesia.

- Yayasan Sarana Wanajaya, Indonesia: 1987-1990, 1991-1995, 1996-2000, 2001-2005.

Specific grants have been received from the following donor agencies:

- Commission of the European Communities, DG-1 Programme 'Ecology in Developing Countries', Brussels, Belgium: 1991-1995.

- Commission of the European Union, DG-1 Programme Tropical Forests, Brussels, Belgium: 1996-2000.

- International Tropical Timber Organization (ITTO), Yokohama, Japan: 1991-1995, 1996-2000.

- Tropenbos Foundation, Wageningen, the Netherlands: 1991-1995.

- International Development Research Centre (IDRC), Ottawa, Canada: 1991-1995.

- Glaxo Wellcome

PROSEA would not exist today without financial support from the above-mentioned donor agencies. For the period 2001-2005 we are financially secure for developing PROSEA Electronics ${ }^{\circledR}$. However, for office management and carrying out other activities, additional financial support from donor agencies is still needed.

\section{PROSEA e-mail addresses}

Correspondence with PROSEA offices can be made through e-mail at the following addresses:

- Network Office, Bogor, Indonesia: info@proseanet.org or pran@proseanet.org

- Country Office Indonesia, Bogor: ariebud@indo.net.id or hadi@proseanet.org

- Country Office Malaysia, Kepong: razak@frim.gov.my or philip@frim.gov.my

- Country Office Papua New Guinea, Lae: tbrookings@fo.unitech.ac.pg.

or tbrookings@hotmail.com

- Country Office Philippines, Los Baños: prosea@ultra.pcarrd.dost.gov.ph or psfaylon@ultra.pcarrd.dost.gov.ph

- Country Office Thailand, Bangkok: daran@mozart.inet.co.th or proseatha@hotmail.com

- Country Office Vietnam, Hanoi: huyen.prosea@fpt.vn

- Publication Office, Wageningen, the Netherlands: prosea@pros.dpw.wag-ur.nl or Jan.Siemonsma@pros.agro.wau.nl 


\section{Conclusion}

Entering the phase beyond 2000, PROSEA already has a strong network, various core outputs and derived products. The PROSEA products will be maintained, further developed, and more rapidly distributed and disseminated. With capital in hand, PROSEA is seeking linkages with the Foundation Flora Malesiana and other organisations to reach its various target groups and to accomplish its mission.

\section{Acknowledgments}

Special thanks are due to Dr J. West and Dr A. Hay, co-chairs of the 5th International Flora Malesiana Symposium, for the invitation to participate in the Stakeholders Minisymposium. The first author is grateful to the UNESCO Jakarta Office, especially Prof. Stephen Hill, for financial support that enabled her to participate in the Symposium held in Sydney, Australia. Our thanks are due to Prof. Washington Napitupulu, the Executive Chairman of the Indonesian National Commission for Unesco, for his encouragement and support that made participation of the first author in the Symposium possible. The first author is thankful to the Director PROSEA Network Office, for the opportunity to attend the Symposium and the encouragement in seeking financial support. Many thanks to our colleagues at the PROSEA Network (especially Dr P.C.M. Jansen) for sharing their thoughts. Thanks are also due to Dini Astriani for her assistance in the preparation of transparencies for our presentation at the Symposium.

\section{References}

Brown, W.H. (1951-1957) Useful plants of the Philippines. Reprint of the 1941-1943 edition. Department of Agriculture and Natural Resources Technical Bulletin No. 10. (Bureau of Printing: Manila).

Burkill, I.H. (1966) A dictionary of the economic products of the Malay Peninsula. Reprint of the 1935 edition with some corrections added. (Ministry of Agriculture and Co-operatives: Kuala Lumpur).

Heyne, K. (1927) De nuttige planten van Nederlandsch Indië. 2nd (enlarged) edition. Vol. 1-3. (Departement van Landbouw, Nijverheid en Handel in Nederlandsch Indië).

Jansen, P.C.M. (1987-2001) The PROSEA Programme (Pant Resources of South-East Asia). Fl. Males. Bull. 9 (4)-12 (7/8).

Kalkman, C. (1989) Economic botany in South-East Asia. Pp. 48-56 in Siemonsma, J.S. and Wulijarni-Soetjipto, N. (eds), Proceedings of the First PROSEA International Symposium, May 22-25, 1989, Jakarta, Indonesia. (Pudoc: Wageningen).

Kartasubrata, J., Riswan, S. and Brotonegoro, S. (eds) (2000) Proceedings of the Third PROSEA International Workshop, November 15-17, 1999, Bogor, Indonesia. (PROSEA Foundation: Bogor).

Nasution, R.E. and Wulijarni-Soetjipto, N. (eds) (1995) Proceedings of the Second PROSEA International Workshop, November 7-9, 1994, Jakarta and Cisarua, Indonesia. (PROSEA Foundation: Bogor).

PROSEA Foundation (2001) Annual Report 2000. (PROSEA Foundation: Bogor).

Reyes, L.G. (1938) Philippine woods. Department of Agriculture and Commerce, Technical Bulletin 7. (Bureau of Printing: Manila).

Siemonsma, J.S. and Wulijarni-Soetjipto, N. (eds) (1989). Proceedings of the First PROSEA International Symposium, May 22-25, 1989, Jakarta, Indonesia. (Pudoc: Wageningen) 
